\title{
The Relationship of Concentration and Accuracy Against Shooting Free Throw Results in High School Students Who Follow Basketball Extracurricular
}

\author{
Doni Pranata ${ }^{1}$, Widiyanto $^{2}$ \\ \{donipranata.2019@student.uny.ac.id ${ }^{1}$,widi@uny.ac.id² $\}$ \\ Yogyakarta State University, Sleman, Indonesia ${ }^{1,2}$
}

\begin{abstract}
This research was conducted against the background of the analysis of the matches when competing basketball and aims to determine whether there is a relationship between concentration and accuracy of the results of free throw shooting on students extracurricular activities in SMA Negeri 2 Palembang. This uses the correlation method. The population used was the high school students of Palembang 2 and the sample of this study was 60 people. The results of this study are as follows the concentration and accuracy has a very weak relationship to the results of shooting freethrow basketball. The correlation coefficient value of 0.374 indicates that there is a relationship between the concentration variable and the accuracy of the free throw is at a low level. From these data it can be concluded that there is a relationship between concentration with free throw shooting results, and also between accuracy with free throw shooting results.
\end{abstract}

Keywords: accuracy, basketball, concentration, free throw

\section{Introduction}

Basketball is a sport that can be played by all ages and is favored by the majority community in children. Basketball is a group ball sport consisting of two teams of five people who compete with each other, collecting points, by entering the ball according to the opponent's basket. Basketball is easy to learn because of the large shape of the ball, so it cannot be played by the player reflecting or throwing the ball [1][2]. There are various aspects that can support athletes in playing basketball. According to observations that took place on the field during a basketball match. From the results held in South Sumatra, namely the DBL (Developmental Basketball League) when the men's basketball team Xaverius 1 Palembang against SMA Negeri 2 Palembang were players not reporting at the time of the match due to factors from in each of their respective players such as stress, anxiety and so on depending on the first quarter and second quarter Palembang team made SMA Negeri 2 a turning point very far from the opposing team as a result there was a lot of risk reversing and analysis when doing free shooting throws. Then, at the break time of the second quarter to the third quarter, a coach instructed to point to a point where each athlete was present with a relaxed body condition and closed his glasses for two minutes with the aim that the athlete could be better suited for this match. 
After being given assistance to focus the minds of the players so they can still support the athlete, in the following quarter, this team can direct the points by attempting to shoot into the ring, even the athletes can win the match with more scores than their opponents. Shooting is a very important skill in a sports basket. Shooting is a technique that can be drilled alone. The basic skill that an athlete must practice is shooting accuracy. Many basketball games are won or lost at the freethrow line [3] This will free the opponent to continue to stick to the player tightly and is easy to fool, and then makes it easy to pass and accompany the ball well (Wissel, 2000: 43) Free throws very often win or lose in matches, so practice free throws in each practice [4]. Accuracy is one's ability to do something carefully, precisely, carefully, thoroughly and accurately. Sajoto in [5]. According to Sajoto in (Nopriadi, 2015: 310) Accuracy (accuracy) is the ability of a person to control the free movement of a target. This goal can be a distance or maybe a direct object that must be worn with one part of the body. Meanwhile, according to Sikumbang, et al., In (Nopriadi, 2015: 32) argues that accuracy is the ability of a person to control movements. As in the implementation of shooting a basketball, kicking the ball toward the goal and others.

Factors that influence concentration during a match are related to outside activities such as school / college, work on assignments and reduce the hours of rest that require increased concentration. Komarudin in [6] Concentration is a very important role in sports because if you experience difficulties, problems will arise. Concentration is very important role in sports because it will be difficult to arise (Komarudin, 2015: 142). According to Wilson, Peper; \& Schmid (2006: 1) Compilation with the ability to focus attention on someone with the task being done and thus cannot be done or supported by external and internal stimuli that are not relevant. According to Setyobroto in (Komarudin, 2015: 134) explains the definition of change relating to two dimensions, namely the dimensions of width (width) and dimensions of concentration (focus).

Based on the background above in this research is to study the relationship of concentration and testing of the results of free throws on students who take basketball extracurricular activities in SMA Negeri 2 Palembang.

\section{Methods}

The method used in this research is quantitative with correlation design. In this research, there are 2 independent variables, namely concentration (X1) and accuracy (X2). While the dependent variable is the result of shooting a free throw basketball (Y).

The population of this research is the students of SMA Negeri 2 Palembang who take extracurricular activities. All 60 SMA Negeri 2 Palembang students. The sample technique used was Judgment sampling. According to Abdurahman, M., Muhidin, S.A., Somatri, A (2011: 143) Judgment sampling (also known as purposive sampling) is a sampling technique that is based on the characteristics set for the target population elements that are adjusted to the objectives or research problems.

Data collection techniques in this study were carried out by giving the paper concentration test grid, to measure concentration, under ring to measure accuracy test and foul shoot test to measure basketball free throw shooting. Data analysis technique used by researchers is the product moment correlation test technique with SPSS 16.0 for Windows program help. 


\section{$3 \quad$ Results and discussion}

There is a significant relationship between concentration and accuracy of the results of free throw shooting in students who take basketball extracurricular activities in SMA Negeri 2 Palembang.

Table 1. Correlation of the value of concentration, accuracy and shooting free throw

\begin{tabular}{llll}
\hline & \multicolumn{3}{c}{ Correlations } \\
\hline & Value of Concentration & Accuracy & Shooting Free Throw \\
\hline Value of Concentration & & .020 & -.005 \\
Pearson Correlation & 1 & .918 & .980 \\
Sig. (2-tailed) & 30 & 30 & 30 \\
$\mathrm{~N}$ & & & \\
Accuracy Pearson & .020 & 1 & .202 \\
Correlation & .918 & & .284 \\
Sig. (2-tailed) & 30 & 30 & 30 \\
$\mathrm{~N}$ & & & \\
ShootingFreeThrow & -.005 & .202 & 1 \\
Pearson Correlation & .980 & .284 & \\
Sig. (2-tailed) & 30 & 30 & 60 \\
$\mathrm{~N}$ & & & \\
\hline
\end{tabular}

This can be seen from the correlation significance value of the concentration value, accuracy and shooting free throw obtained correlation value between concentration and accuracy of 0.20 , concentration and shooting free throw 0.05 , accuracy and shooting free throw 0.202 . to determine the level of correlation and relationship of a data can be seen from table 2.

Table 2. Guidelines for providing correlation coefficient interpretations

\begin{tabular}{ll}
\hline Correlation Coefficient Intervals & Relationship Level \\
\hline $0,00-0,199$ & Very weak \\
$0,20-0,399$ & Weak \\
$0,40-0,599$ & Middle \\
$0,60-0,799$ & Strong \\
$0,80-1,000$ & Very strong \\
\hline
\end{tabular}

From this table it can be seen that the degree of relationship between concentration and accuracy is weak, accuracy and free throw shooting are weak, and concentration and free throw shooting are very weak.

The correlation between the concentration and accuracy variables on the results of free throw shooting on students who take extracurricular basketball has a positive direction, meaning that the direction is the lower the level of concentration and accuracy possessed by the player, the more inappropriate the shot taken at the player when shooting free throw, vice versa. Concentration emphasizes the athlete's ability to focus his attention on the stimulus chosen by him in a predetermined period of time. to raise the definition of concentration to the surface taken from the definitions put forward by experts sourced from the book Komarudin (2015: 134). according to Slameto in (Rahmayani 2017: 7) Concentration is to focus the mind 
on a particular object by putting aside things that are not related to the learning and teaching process carried out. Komarudin in [7] which states that "Concentration is very important role in sports because if disturbed then problems will arise. Especially in sports that require accuracy of throws, punches, kicks and shots on target, with the concentration of these activities will run smoothly and in accordance with the wishes. According to Satiadarma in [8] concentration is an important aspect of sports not only during matches but also during training. According to Komarudin in (Sunawa et al., 2018) Concentration is a very important role in sports because if disturbed then problems will arise. Concentration is the ability to maintain focus on activities that exist in a rapidly changing environment on thoughts about the past or future that cause unrelated cues and often make chaotic appearances in Mylsidayu in [9]. According to [10] Concentration is a condition in which a person's consciousness is focused on a particular object with a certain time, the better the concentration the longer. One way concentration is one aspect of a target that is bigger than the one on the card.

The results of the relationship in this study are very low because the average subject has a low concentration level, which results in a low free throw shooting. The lower the concentration level of the player, the more difficult for players to score when shooting free throw, and vice versa high concentration can create good shots and score a lot in free throw shooting. Accuracy is the ability to direct a motion to a target in accordance with its objectives. Accuracy is the fit between the will (desired) and the reality (results) obtained against certain goals (objectives) Suharno in (Andita, 2015: 12). Accuracy is defined as an individual's skill to direct an object precisely to the desired target, as stated by Ahmadi in [11]. According to Sajoto in (Nopriadi, 2015: 310) accuracy (accuracy) is the ability of a person to control the free movements of a target. This target can be a distance or maybe a direct object that must be worn with one part of the body. According to [12] the accuracy required while a player who can score at all stages of the game under different conditions is very important for accuracy in shooting and winning. Meanwhile, according to Sikumbang, et al., In (Nopriadi, 2015: 32) argues that accuracy is the ability of a person to control movements. As in the implementation of basketball shooting, kicking the ball toward the goal and others. According to Abdurahman et al (2011: 133) accuracy (accuracy) is how carefully the tool measures what should be measured, so accuracy speaks of the distance measured from the target. The hypothesis of the contribution of accuracy and the results of extracurricular basketball free throw shooting at SMA Negeri 2 Palembang amounted to $r=0.202$ if it was presented to be $20.2 \%$ indicating the relationship obtained was weak.

The relationship results in this study are low because the average subject has a low level of accuracy, so it results in a low free throw shooting too. The lower the level of accuracy of the player, the more difficult players will score when shooting free throw, and vice versa high accuracy can create good shots and score a lot in free throw shooting. Shooting free throw, according to Karsono in (SMA \& SLEMAN, n.d.) that shooting is the last target of every play. The ability of a team in research is always determined by the ability to play in shooting, therefore the element of shooting is a basic technique that must be learned properly and correctly and improved skills with practice. According to [13] free throw is a gift given by the referee to the player to score one number in a position directly behind the free throw line. Free throwing is usually given if the opposing player violates a prohibited area. Boot free throw is an opportunity given by a person players to score one number, not guarded, from a position behind the free throw line and inside the circle (Perbasi, 2016: 45). towards further study by providing a link between the results of the analysis achieved with the theory. According to Hall Wissel in (Sunawa et al., 2018) explains that in doing the free throw standing technique 
one of them is to pay attention to views, the intended point is that the player must focus on the meaning of the goal when performing the free throw standing technique that requires high concentration. According to Price, Jayme; Gill, Diane L.; Etnier, Jennifer; Kornatz, Kurt, (2009: 719) successful free-throw requires attention skills and physical abilities; Therefore, understanding the attention demands of skills can provide guidanc out the results to be achieved, 2) Thinking about events (failure), 3) Feeling depressed, 4) Physiological disorders, 5) Fatigue and 6) Poor motivation.

\section{Conclusion}

The low correlation results in this study are due to the low level of concentration in the players, namely where the players feel unable to understand and master their thoughts and feelings, so they are unable to focus attention at one point. Concentration is a skill that is very difficult for athletes to master, therefore concentration must be trained by the coach because if an athlete fails to control his concentration the athlete is difficult to predict to be able to focus on doing his job well, and difficult to predict to be able to win the match (Komarudin, 2015: 135). Inability experienced by athletes is influenced by the stimulus that is around the player and the stimulus that is in the player. When players are tired or tired, it will affect the subject in the game, when the research takes place, it is very obvious that the subject is not enthusiastic and looks tired because of lack of rest because after school. This is as expressed by Schmid, et al [14] that the influence of internal stimulus and external stimulus can affect one's concentration. According to [15] explain the factor of concentration disturbances from the athlete's internal (internal) there are several factors, including: 1) thinking ab

In this research, it can be concluded that there is a significant relationship between concentration and accuracy of the results of free throw shooting in students who take basketball extracurricular activities in SMA Negeri 2 Palembang. This can be seen from the correlation significance value of the concentration value, accuracy and shooting free throw obtained correlation value between concentration and accuracy of 0.20 , concentration and shooting free throw 0.05, accuracy and shooting free throw 0.202. to determine the level of correlation and relationship of a data can be seen from table 3.6. from the table it can be seen that the degree of relationship between concentration and accuracy is weak, accuracy and shooting of free throw are weak, and concentration and shooting of free throw are very weak. The low correlation in this study is due to the inability experienced by athletes to be influenced by the stimulus that is around the player and the stimulus that is in the player. When players are tired or tired, it will affect the subject in the game, when the research takes place, it is very obvious that the subject is not enthusiastic and looks tired because of lack of rest because after school.

\section{References}

[1] Susanto. Praktik Permainan Bola Besar. Jakarta: CV Rama Edukasitama; 2013.

[2] Susanto O. Praktik Permainan Bola Besar. Jakarta Timur CV Rama Edukasitama. 2013;

[3] Tran CM, Silverberg LM. Optimal release conditions for the free throw in men's basketball. J Sports Sci. 2008;26(11):1147-55.

[4] Kosasih D. Fundamental basketball first step to win. Semarang: Karangturi Media; 2008. 
[5] Ridwan M. PENGARUH LATIHAN MENGGUNAKAN MEDIA TALI DAN SIMPAI TERHADAP AKURASI TEMBAKAN BEBAS (FREE THROW) PERMAINAN BOLA BASKET SISWA PUTRA EKSTRAKURIKULER SMA NEGERI 15 BANDAR LAMPUNG. 2016;

[6] Sunawa MK, Rustiadi T, Soekardi S. The Contribution of Hand-Eye Coordination, Muscle Arm Strength, and Concentration to Standing Throw Shoot Results. J Phys Educ Sport. 2018;7(2):14151.

[7] INDRA CAHYA Y. Hubungan Tingkat Konsentrasi Siswa Terhadap Hasil Akhir Under Basket Shoot Bola Basket (Studi pada peserta ekstrakurikuler bola basket di SMAN 11 Surabaya). J Pendidik Olahraga dan Kesehat. 2017;5(3).

[8] Jamaliah N, Kasmini OW. PENGARUH HYPNOTHERAPY DAN TINGKAT KECEMASAN TERHADAP KONSENTRASI ATLET PUTRI CLUB PEKERJAAN UMUM (PU) DELI SERDANG SUMATERA UTARA TAHUN 2015. J Phys Educ Sport. 2015;4(1).

[9] Kuswoyo DD, Pramono H, RC AR. Kontribusi Percaya Diri, Konsentrasi dan Motivasi terhadap Kinerja Wasit Persatuan Sepak Bola Seluruh Indonesia Provinsi Sumatera Selatan. J Phys Educ Sport. 2017;6(3):241-7.

[10] Meirizal U. Positive Thinking To Improve Performance Achievement Athlete. In: Asean Sport University International Conference (AUSCIC). AUSCIC 2014; 2014. p. 210-5.

[11] KRISNA SARI R. KONTRIBUSI TINGKAT KECEMASAN TERHADAP KETEPATAN PASING BAWAH PADA CABANG OLAHRAGA BOLAVOLI (Studi Pada Tim Ekstrakurikuler SMAN 1 Menganti). J Kesehat Olahraga. 2016;4(4).

[12] Dominic OL, Chado MA, Gwani JA, Dikki CE. Interplay Among Physical Characteristics Play Position And Shooting Accuracy Of Elite-Female Basketballers. Act J Phys Educ Sport Heal Recreat. 2018;7(2):90-6.

[13] Hardiyono B. PENGARUH METODE LATIHAN SHOOTING TERHADAP HASIL SHOOTING FREE THROW. Altius J Ilmu Olahraga dan Kesehat. 2017;6(2).

[14] Anggraeni Putri S. HUBUNGAN ANTARA KONSENTRASI DENGAN KETEPATAN FREE THROW PADA PEMAIN BOLA BASKET SMA NEGERI 3 SIDOARJO PADA SAAT LATIHAN. Character J Penelit Psikologi. 2017;5(1).

[15] Weinberg RS, Gould D. Foundations of sport and exercise psychology, 7E. Human Kinetics; 2018. 